


\author{
The Crisis of the \\ Early Italian Renaissance
}





\section{The Crisis of the}

\section{Early Italian Renaissance}

Civic Humanism and Republican Liberty in an Age of Classicism and Tyranny

BY HANS BARON

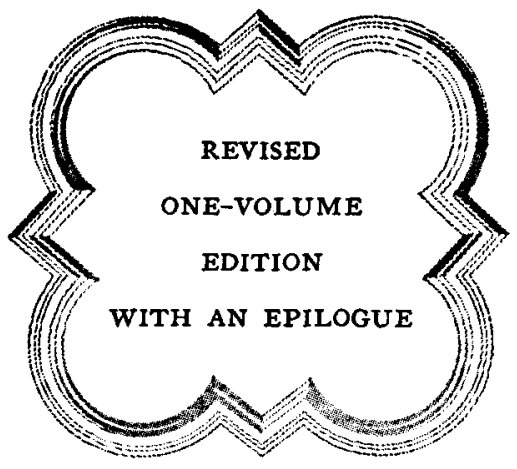

PRINCETON, NEW JERSEY

PRINCETON UNIVERSITY PRESS

PUBLISHED IN COOPERATION WITH THE NEWBERRY LIBRARY

I 966 
Published by Princeton University Press

41 William Street

Princeton, New Jersey 08540

In the United Kingdom: Princeton University Press

Chichester, West Sussex

Copyright $\odot 1966$ by Princeton University Press

All Rights Reserved

Library of Congress Card No. 66-10549

ISBN 0-691-00752-7 (paperback)

Second printing, 1967

Eighth printing, 1993

Princeton University Press books are printed on acid-free paper and meet the guidelines for permanence and durability of the

Committee on Production Guidelines for Book

Longevity of the Council on Library Resources

$\begin{array}{lllllllll}9 & 11 & 13 & 15 & 16 & 14 & 12 & 10 & 8\end{array}$

Printed in the United States of America 
To the Memory of

Garrett Mattingly 
